\title{
ANALISIS SISTEM INFORMASI JADWAL TERPADU BERBASIS WEBSITE
}

\author{
Ridho Dedy Arief Budiman' ${ }^{1}$, Dochi Ramadhani' ${ }^{2}$, \\ Umi Liwayanti ${ }^{3}$, Ulil Albab ${ }^{4}$ \\ 1,2,3,4 Pendidikan Teknologi Informasi dan Komputer IKIP PGRI Pontianak \\ Jalan Ampera Nomor 88 Pontianak \\ 1e-mail: ridho.asytarrazi@gmail.com
}

\begin{abstract}
Abstrak
Tujuan penelitian adalah menganalisis sistem informasi jadwal terpadu di Program Studi Pendidikan Teknologi Informasi dan Komputer (PTIK) IKIP PGRI Pontianak. Metode penelitian adalah deskriptif kualitatif. Subjek penelitian berjumlah 15 orang yang terdiri dari 10 mahasiswa, 4 dosen, dan 1 staf Program Studi PTIK. Alat pengumpulan data menggunakan wawancara dengan teknik pengumpul data menggunakan panduan wawancara. Teknik analisis data menggunakan analisis deskriptif kualitatif. Analisis Sistem Jadwal Terpadu Program Studi PTIK yang dilakukan meliputi jadwal perkuliahan, jadwal dosen pembimbing skripsi, serta jadwal seminar dan skripsi. Hasil penelitian menunjukkan: (1) sistem berjalan yang digunakan tidak memiliki karakteristik usability, functionality, dan visual communication; dan (2) usulan sistem yang baru berbentuk alur program dengan memperhatikan karakteristik usability, functionality, dan visual communication.
\end{abstract}

Kata Kunci: sistem informasi, database, jadwal terpadu.

\begin{abstract}
The purpose of the research was to analyze the integrated schedule information system in the Computer and Information Technology Education Study Program (PTIK) IKIP PGRI Pontianak. The research method used descriptive qualitative. The research subjects were 15 people consisting of 10 students, 4 lecturers, and 1 staff of the PTIK Study Program. Data collection tools used interviews with data collection techniques used interview guides. The data analysis technique used a qualitative descriptive analysis. Analysis of the integrated schedule system of the PTIK Study Program which is carried out includes lecture schedules, thesis supervisor schedules, and seminars or thesis schedules. The results of the research were: (1) the running system used did not have the characteristics of usability, functionality, and visual communication; and (2) the proposed new system is in the form of a program flow by taking into account the characteristics of usability, functionality, and visual communication.
\end{abstract}

Keywords: information system, database, integrated schedule.

\section{PENDAHULUAN}

Program Studi Pendidikan Teknologi Informasi dan Komputer (PTIK) IKIP PGRI Pontianak belum memiliki sistem informasi yang terkomputerisasi (terdigitalisasi) terkait informasi jadwal dosen mengajar, jadwal dosen melakukan bimbingan, serta jadwal mahasiswa seminar dan sidang skripsi. Program Studi PTIK hanya menggunakan papan pengumuman saja dalam menyajikan informasi 
tersebut. Penggunaan papan pengumuman memiliki berbagai kendala, seperti penggunaan spidol yang mudah terhapus dan sulitnya tulisan tangan terbaca oleh mahasiswa karena jarak yang jauh. Berdasarkan keadaan tersebut, pengembangan sistem informasi jadwal terpadu akan mengatasi atau mengurangi permasalahan yang terjadi. Dengan menggunakan sistem terkomputerisasi, maka informasi yang disajikan akan lebih akurat dan mempersingkat waktu pencarian (Tinambunan, dkk., 2018; Bakti, dkk., 2016; Halawa, 2016; Syapnika dan Siagian, 2015; Zukri dan Winarko, 2014). Hasil penelitian yang pernah dilakukan menyatakan bahwa melalui sistem informasi, setiap aktor dalam sistem yang dibangun akan memperoleh laporan yang terjamin akurasinya serta tidak memerlukan waktu yang lama dalam memprosesnya (Setyawan, dkk., 2017). Hal tersebut juga berarti bahwa dengan sistem komputerisasi, maka proses pengolahan data akan semakin tepat dan mengurangi kesalahan dalam memprediksi (Ulfa, dkk., 2016).

Bentuk sistem informasi yang banyak dikembangkan adalah sistem informasi berbasis website dengan memperhatikan karakteristik usability, functionality, dan visual communication. IKIP PGRI Pontianak telah menyediakan layanan internet yang memadai serta dapat diakses oleh dosen dan mahasiswa yang tentunya memudahkan dalam mengakses sistem informasi yang akan dikembangkan. Dari segi kesiapan calon pengguna, baik dosen maupun mahasiswa telah terbiasa menggunakan website untuk memasukkan data sehingga pengembangan aplikasi tidak akan memerlukan adaptasi yang lama (Kristy, 2020; Budiman, dkk., 2018; Waryanto dan Insani, 2013). Halaman website pada awalnya hanya merupakan ruang informasi yang menggunakan teknologi hypertext dan menuntun pengguna untuk mengakses link yang telah disediakan dan ditampilkan dalam website browser (SIRKEL Laboratorium, 2008).

Halaman website sekarang merupakan standar tampilan bagi layanan website. Aplikasi website terbagi menjadi dua, yaitu website statis dan website dinamis. Website statis merupakan halaman website yang hanya terdiri dari bahasa hypertext markup language (HTML) dan perubahan data pada halaman website dilakukan secara manual yaitu dengan mengubah skrip HTML. Sedangkan website dinamis merupakan halaman website yang terdiri dari PHP, CSS, Oracle 
sebagai media penyimpanan, dan bahasa pemrograman lainnya sebagai penunjang halaman website.

Penggunaan website tentunya tidak terlepas dari manfaat yang diberikan. Berbagai manfaat seperti kemampuan menghilangkan batas ruang dan waktu, artinya melalui website yang terhubung dengan internet seseorang dapat terhubung dengan orang lain meskipun berada di tempat yang jauh. Kemampuan lain adalah kecepatan memperoleh informasi, melalui website berbagai kejadian di dunia dapat diperoleh dengan hitungan detik. Kemampuan website tersebut didukung dengan semakin mudahnya pengoperasian perangkat komputer, kemudahan mendapatkan akses internet, terjangkaunya perangkat komputer, dan biaya penggunaan internet yang semakin terjangkau. Keuntungan lain menggunakan sistem informasi berbasis website akan dirasakan oleh pimpinan Program Studi PTIK. Melalui sistem informasi jadwal terpadu berbasis website, pimpinan Program Studi PTIK dapat memantau proses pembelajaran dan bimbingan yang diberikan dosen kepada mahasiswa. Hal tersebut akan membantu proses evaluasi di Program Studi PTIK. Hasil penelitian terdahulu menyatakan bahwa sistem informasi kehadiran mahasiswa akan memudahkan dalam menghasilkan laporan periodic dan incidental (Irawan dan Noor, 2014).

Berdasarkan keuntungan yang diperoleh dengan menggunakan sistem informasi jadwal terpadu berbasis website, maka perlu dilakukan pengembangan Sistem Informasi Jadwal Terpadu pada Program Studi PTIK IKIP PGRI Pontianak. Langkah awal dari pengembangan sistem informasi jadwal terpadu tersebut adalah melakukan analisis terhadap sistem informasi yang digunakan (sistem berjalan) dan kemudian membuat sistem informasi yang diusulkan (sistem usulan) berdasarkan pada hasil analisis yang dilakukan di Program Studi PTIK IKIP PGRI Pontianak.

\section{METODE}

Penelitian menggunakan metode deskriptif kualitatif. Subjek penelitian berjumlah 15 orang yang terdiri dari 10 mahasiswa, 4 dosen, dan 1 staf Program Studi PTIK. Teknik analisis data menggunakan analisis deskriptif kualitatif. 
Penelitian membahas tentang permasalahan dalam penerapan sistem berjalan yang meliputi jadwal perkuliahan, jadwal dosen pembimbing skripsi, serta jadwal seminar dan skripsi. Hasil analisis sistem berjalan yang masih belum terdigitalisasi kemudian menjadi dasar peneliti dalam menyusun alur dari sistem usulan berbasis website. Alat pengumpulan data menggunakan wawancara dengan teknik pengumpul data menggunakan panduan wawancara. Indikator yang digunakan dalam panduan wawancara meliputi aspek usability, functionality, dan visual communication dari sistem yang ada. Hasil wawancara dilakukan triangulasi, baik dari segi data maupun sumber.

\section{HASIL DAN PEMBAHASAN}

\section{Analisis Sistem Berjalan}

Analisis sistem berjalan merupakan penguraian dari suatu sistem untuk mengidentifikasi dan mengevaluasi permasalahan yang terjadi. Analisis sistem yang dilakuan meliputi jadwal perkuliahan, jadwal dosen pembimbing skripsi, serta jadwal seminar dan skripsi. Hasil analisis sistem berjalan digambarkan dalam bentuk data flow diagram (DFD).

\section{Analisis sistem berjalan jadwal perkuliahan}

Alur sistem berjalan sistem jadwal perkuliahan terlihat pada Gambar 1.

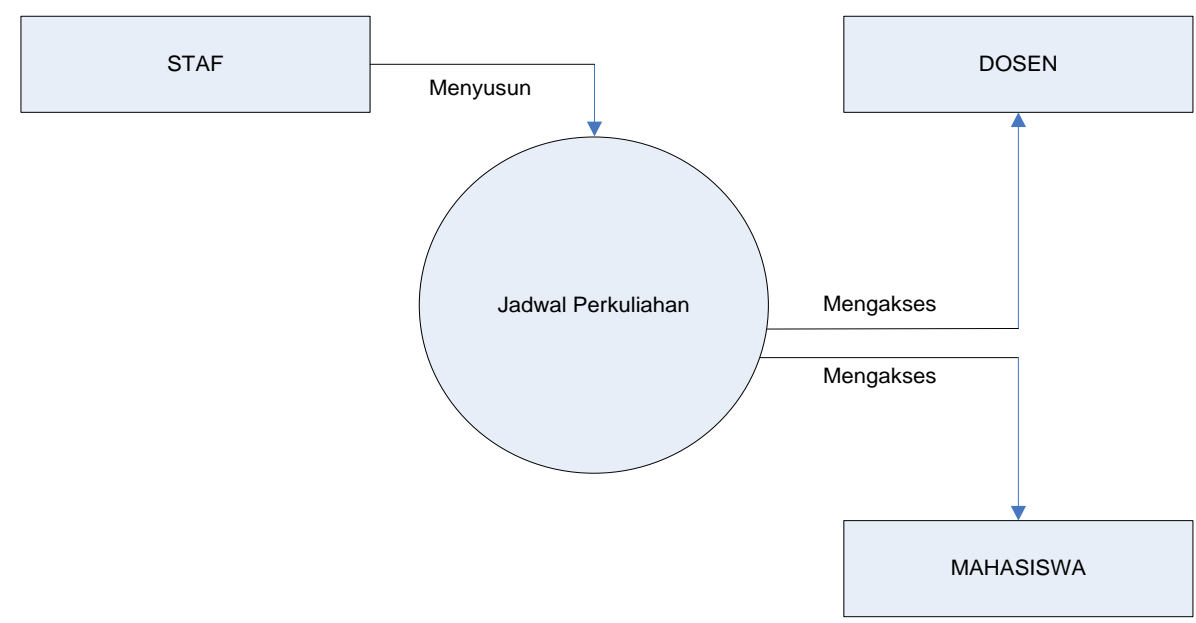

Gambar 1 DFD Sistem Berjalan Jadwal Perkuliahan 
Berdasarkan Gambar 1, terlihat bahwa untuk mendapatkan informasi mengenai jadwal perkuliahan, dosen dan mahasiswa harus melakukan konfirmasi ke staf yang ada di Program Studi PTIK secara manual. Staf kemudian melakukan pengecekan terhadap jadwal perkuliahan yang diperlukan informasinya oleh dosen maupun mahasiswa. Hal tersebut memerlukan waktu yang tidak sebentar, sehingga pemanfaatan waktu menjadi tidak efektif (Effendi dan Noviansyah, 2018; Sari dan Muhartini, 2017; Senna dan Supriyono, 2016; Sundari, 2016; Kurniadi, 2014).

\section{Analisis sistem berjalan jadwal dosen pembimbing skripsi}

Alur sistem berjalan sistem jadwal dosen pembimbing skripsi terlihat pada Gambar 2.

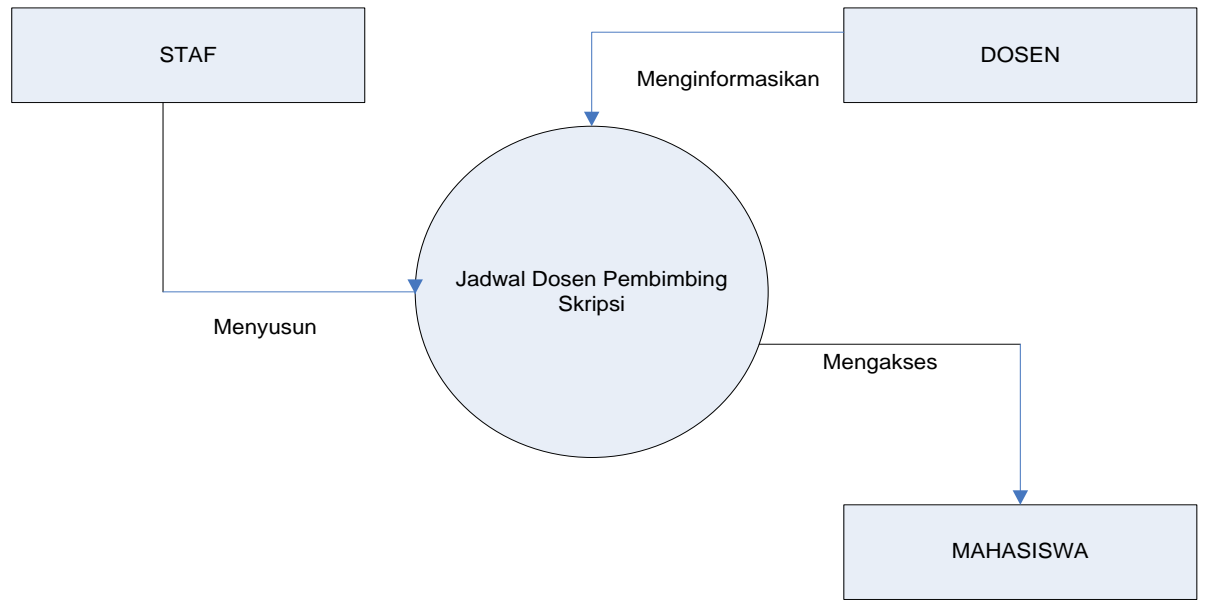

\section{Gambar 2 DFD Sistem Berjalan Jadwal Dosen Pembimbing Skripsi}

Berdasarkan Gambar 2, terlihat bahwa staf Program Studi PTIK melakukan pembagian dosen pembimbing skripsi, kemudian dosen pembimbing skripsi menginformasikan jadwal yang disediakan untuk melakukan bimbingan skripsi. Selanjutnya untuk mengetahui jadwal dosen pembimbing skripsi, mahasiswa harus melakukan konfirmasi ke staf di Program Studi PTIK secara manual.

\section{Analisis sistem berjalan jadwal seminar dan skripsi}

Alur sistem berjalan untuk sistem jadwal jadwal seminar dan skripsi terlihat pada Gambar 3. 


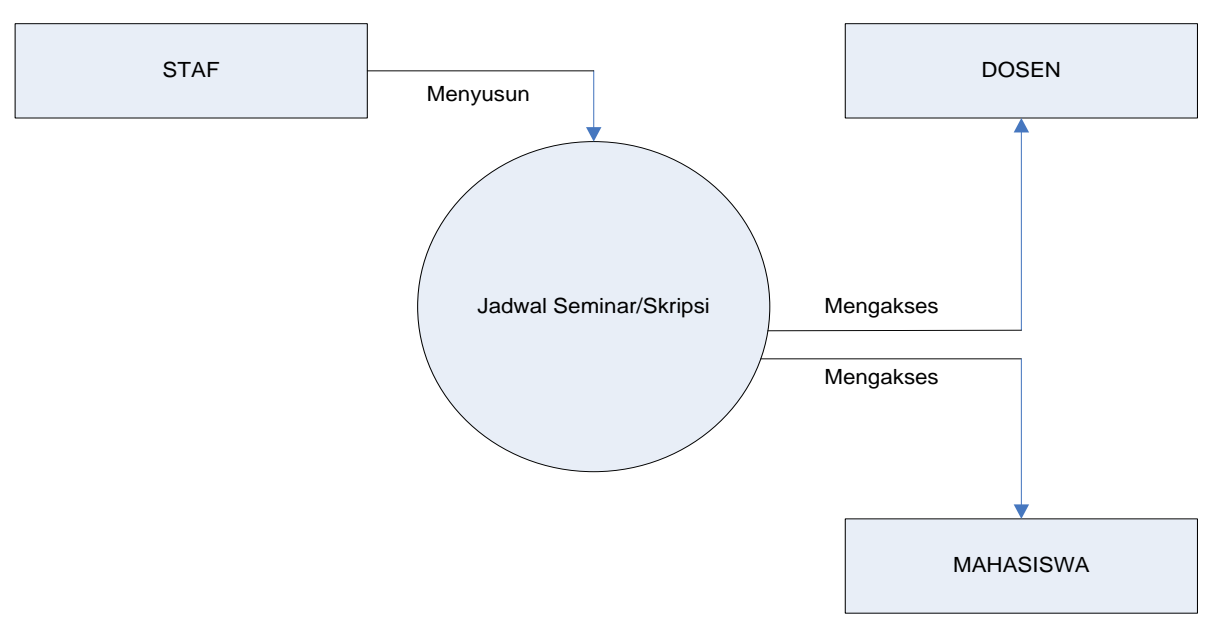

\section{Gambar 3 DFD Sistem Berjalan Jadwal Seminar dan Skripsi}

Berdasarkan Gambar 3, terlihat bahwa untuk mengetahui jadwal seminar dan skripsi yang akan berlangsung, mahasiswa dan dosen harus melakukan konfirmasi ke staf di Program Studi PTIK secara manual.

Analisis sistem berjalan dilakukan dengan tujuan untuk mengidentifikasi masalah-masalah yang sedang terjadi pada sistem berjalan sehingga dapat dilakukan perbaikan-perbaikan terhadap kelemahan sistem tersebut. Berdasarkan hasil wawancara, kegiatan monitoring jadwal terpadu yang meliputi jadwal perkuliahan, jadwal dosen pembimbing skripsi, serta jadwal seminar dan skripsi di Program Studi PTIK tidak memiliki karakteristik usability, functionality, dan visual communication. Hal tersebut terjadi dikarenakan semua proses dilakukan secara manual dan belum terdigitalisasi. Oleh karenanya, peneliti menyusun sistem usulan yang memiliki karakteristik usability, functionality, dan visual communication berbasis website.

\section{Analisis Sistem yang Diusulkan}

Berdasarkan pada identifikasi masalah dan penyebab masalah yang telah diuraikan, maka disimpulkan bahwa masalah-masalah utama yang dihadapi pada sistem berjalan dapat diatasi dengan merancang sistem baru yang khusus untuk melakukan pemantauan jadwal perkuliahan, jadwal bimbingan skripsi, serta jadwal seminar dan skripsi. Sistem informasi tersebut mempunyai nilai lebih dibanding proses penjadwalan yang sudah ada karena penggunaannya 
berkesinambungan dan mudah menyesuaikan dengan perubahan format dan data, tampilan yang mudah dipahami penggunaannya serta validasi data masukan. Dengan penggunaan sistem baru, terdapat penyederhanaan proses sehingga sistem lebih ringkas dan terotomatisasi serta memudahkan pengguna dalam memproses data yang diperlukan. Hal tersebut sesuai dengan hasil penelitian yang menyatakan bahwa dengan penerapan aplikasi terkomputerisasi, maka akan memberikan kemudahan dan kenyamanan dalam penggunaannya (Arizal, dkk., 2019; Arpan, dkk., 2018; Djumhadi, 2017; Mendra, 2017; Purabaya, 2017; Berutu, 2016).

Rancangan sistem usulan berupa sistem jadwal terpadu yang mampu mengatasi permasalahan yang dihadapi sistem berjalan. Adapun perbaikan yang dilakukan pada sistem usulan berupa penyederhanaan proses yang ada pada sistem berjalan sehingga menjadi lebih efektif dan efisien (Siregar, 2019; Susilo dan Rohman, 2017; Lestanti dan Susana, 2016; Yudha dan Sinatra, 2016) serta menampilkan jadwal secara digital dengan memperhatikan karakteristik usability, functionality, dan visual communication (Ahdan, dkk., 2020; Yunita dan Susanto, 2020; Asrori dan Putri, 2019; Ramadi, 2016).

Jadwal terpadu pada Program Studi PTIK terbagi menjadi beberapa proses yang dilakukan berdasarkan urutan: (1) staf melakukan penyusunan jadwal yang terdiri dari jadwal perkuliahan, jadwal dosen pembimbing skripsi, serta jadwal seminar dan skripsi; (2) berdasarkan hasil penyusunan yang dilakukan oleh staf, maka tersusunlah jadwal perkuliahan, jadwal dosen pembimbing skripsi, serta jadwal seminar dan skripsi; dan (3) setelah jadwal tersusun, maka staf dapat melakukan pencetakan jadwal perkuliahan dan menyebarkannya ke dosen dan mahasiswa, serta ditampilkan pada layar monitor.

\section{Flowmap sistem usulan}

Alur Sistem Informasi Jadwal Terpadu pada Program Studi PTIK yang diusulkan terlihat pada Gambar 4. Berdasarkan Gambar 4, terlihat bahwa staf berperan untuk memasukkan data jadwal mata kuliah, jadwal bimbingan dosen, serta jadwal seminar dan skripsi. Staf dapat melakukan rekap dengan mencetak 
jadwal. Sedangkan dosen dan mahasiswa sebagai pengguna menerima informasi dari sistem.

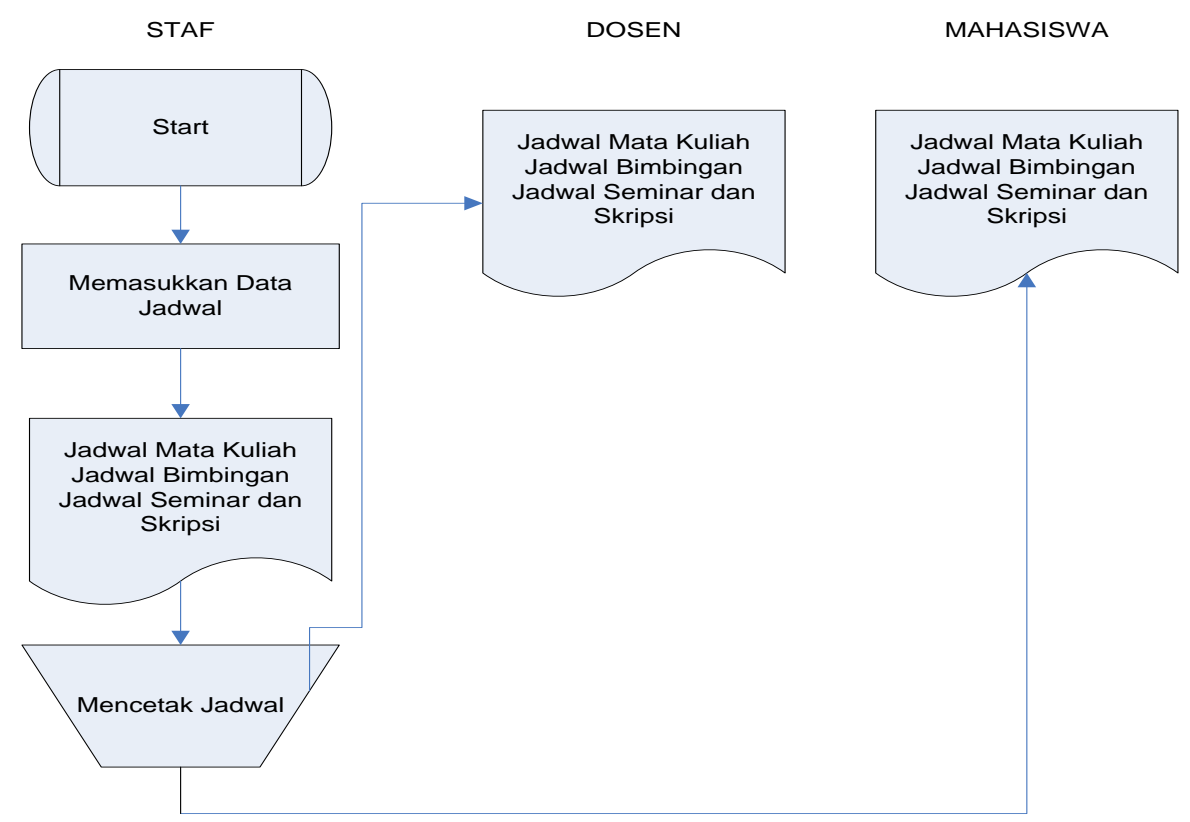

\section{Gambar 4 Flowmap Sistem Usulan}

\section{Data flow diagram (DFD) yang diusulkan}

DFD Sistem Informasi Jadwal Terpadu pada Program Studi PTIK yang diusulkan terbagi menjadi DFD Konteks, DFD Berjenjang, dan DFD Rinci. DFD Konteks Sistem Terpadu pada Program Studi PTIK yang diusulkan terlihat pada Gambar 5.

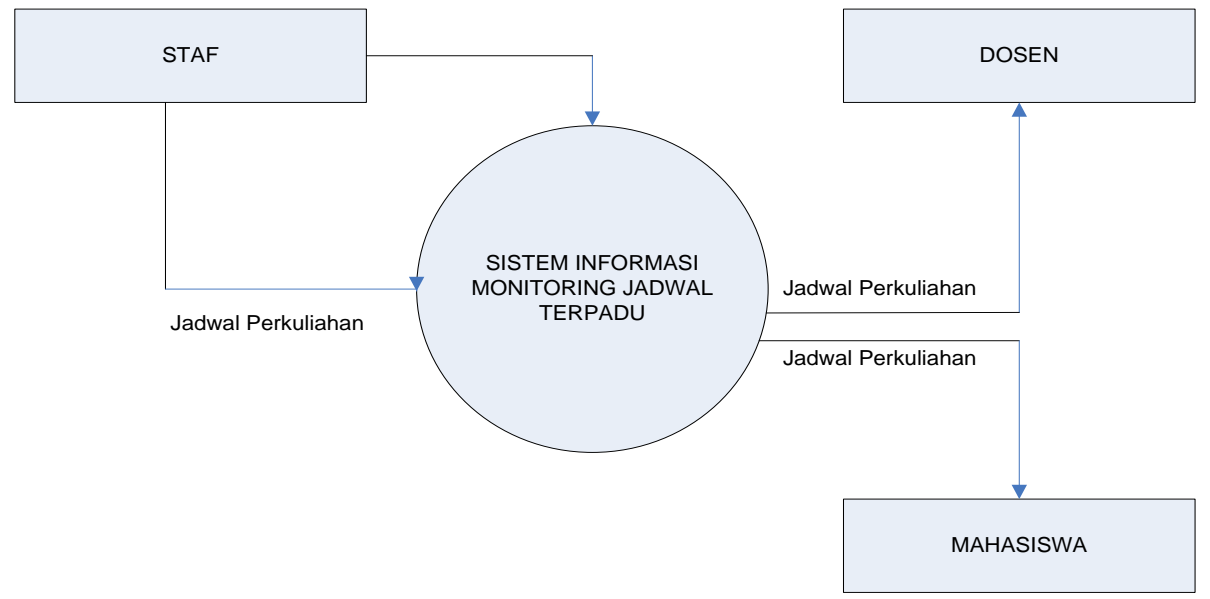

Gambar 5 DFD Konteks Sistem yang Diusulkan 
DFD Berjenjang Sistem Informasi Jadwal Terpadu pada Program Studi PTIK yang diusulkan terlihat pada Gambar 6.

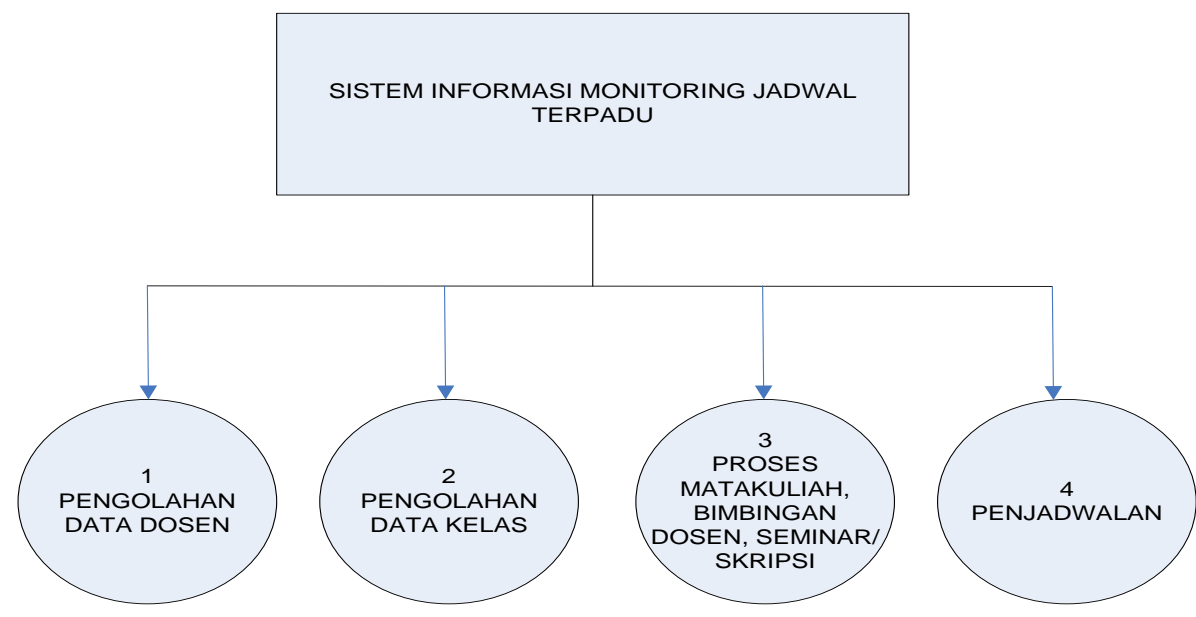

Gambar 6 DFD Berjenjang Proses yang Diusulkan

DFD Rinci Sistem Informasi Jadwal Terpadu pada Program Studi PTIK yang diusulkan terlihat pada Gambar 7.

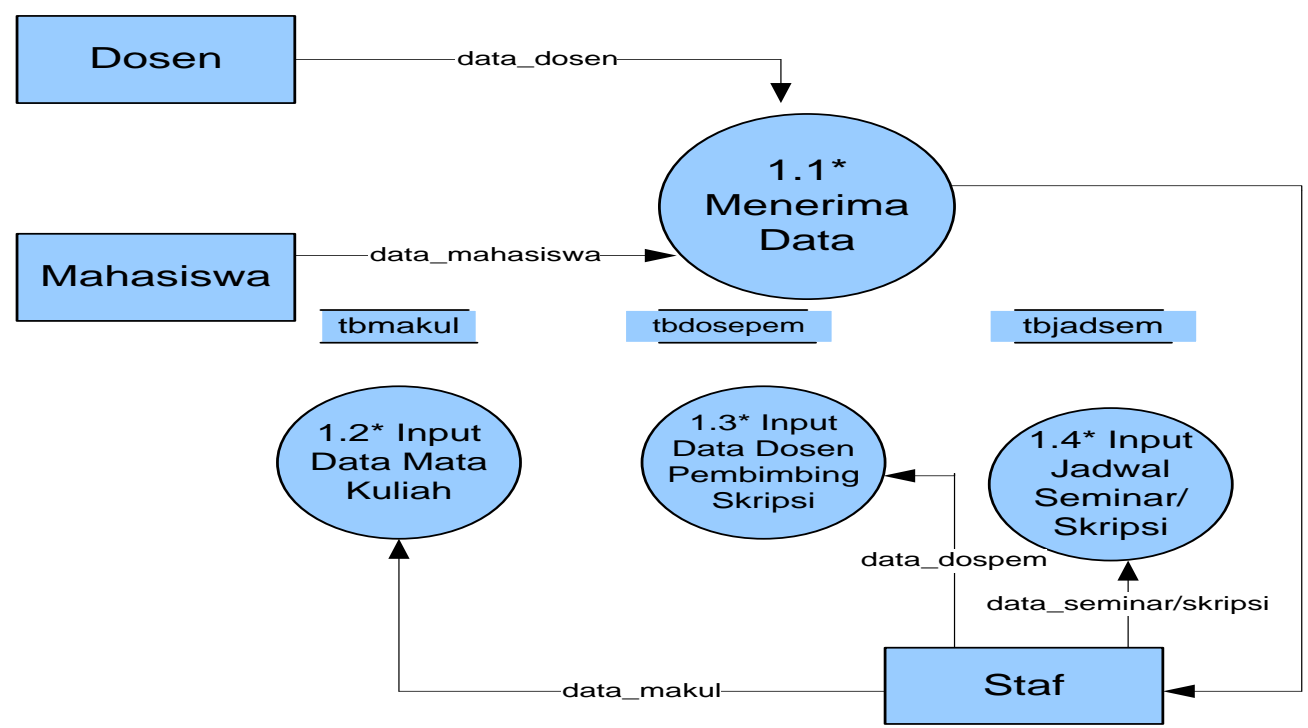

Gambar 7 DFD Rinci Proses yang Diusulkan

Simbol bintang (*) pada Gambar 7 berarti bahwa suatu proses sudah selesai, sehingga tidak bisa dirincikan ke jenjang berikutnya. Uraian dari Gambar 7 adalah sebagai berikut.

\section{Proses Rinci 1.1* - Menerima Data}

Staf menerima data dosen dan mahasiswa untuk direkap. 


\section{Proses Rinci 1.2* - Input Data Mata Kuliah}

Data yang telah diklasifikasikan oleh Staf akan dimasukkan ke database mata kuliah.

\section{Proses Rinci 1.3* - Input Data Dosen Pembimbing Skripsi}

Data yang telah diklasifikasikan oleh staf akan dimasukkan ke database dosen pembimbing.

\section{Proses Rinci 1.4* - Input Jadwal Seminar dan Skripsi}

Data yang telah diklasifikasikan oleh staf akan dimasukkan ke database jadwal seminar dan skripsi.

\section{SIMPULAN}

Berdasarkan hasil analisis sistem berjalan dan desain sistem yang diusulkan, maka disimpulkan: (1) kegiatan sistem berjalan yang meliputi jadwal perkuliahan, jadwal dosen pembimbing skripsi, serta jadwal seminar dan skripsi pada Program Studi PTIK tidak memiliki karakteristik usability, functionality, dan visual communication karena dilakukan secara manual, sehingga sistem belum terdigitalisasi; dan (2) usulan sistem yang baru berbentuk alur program yang digunakan untuk melakukan pengolahan data yang menghasilkan output berupa jadwal perkuliahan, jadwal dosen pembimbing skripsi, serta jadwal seminar dan skripsi dengan memperhatikan karakteristik usability, functionality, dan visual communication.

\section{UCAPAN TERIMA KASIH}

Terima kasih peneliti ucapkan kepada IKIP PGRI Pontianak yang telah memberikan bantuan dana penelitian melalui LPPM IKIP PGRI Pontianak dengan nomor kontrak penelitian 016/L.202/PK/III/2020.

\section{DAFTAR PUSTAKA}

Ahdan, S., Putri, A. R., \& Sucipto, A. 2020. Aplikasi M-Learning sebagai Media Pembelajaran Conversation pada Homey English. SISTEMASI: Jurnal Sistem Informasi, 9(3): 493-509. 
Arizal, Budiharto, I., \& Nurfianti, A. 2019. Analisis Rencana Penerapan Sistem Informasi dalam Pendokumentasian Asuhan Keperawatan di Rumah Sakit Universitas Tanjungpura. BIMIKI (Berkala Ilmiah Mahasiswa Ilmu Keperawatan Indonesia), 7(2): 19-29.

Arpan, M., Budiman, R. D. A., \& Jalinus, N. 2018. Usulan Sistem Pengolahan Data Siswa di SMP Harapan Ananda Kubu Raya. Jurnal Pendidikan Informatika dan Sains, 7(2): 271-280.

Asrori, R. \& Putri, A. R. 2019. Pengembangan Aplikasi Sistem Informasi Pelanggaran Tata Tertib Siswa Berbasis Android di SMK Negeri 2 Boyolangu. JoEICT(Jurnal of Education and ICT), 3(2): 118-129.

Bakti, S., Hasibuan, N. A., Sianturi, L. T., \& Sianturi, R. D. 2016. Perancangan Aplikasi Pembelajaran CorelDraw X3 Menggunakan Metode Web Based Learning (WBL). Jurnal Riset Komputer (JURIKOM), 3(4): 32-35.

Berutu, W. 2016. Perancangan Aplikasi Palang Pintu Otomatis Menggunakan Motion Sensor Berbasis Mikrokontroler AT89S51. Jurnal Riset Komputer (JURIKOM), 3(1): 96-101.

Budiman, R. D. A., Arpan, M., \& Verawardina, U. 2018. Readiness Assessment Penerapan Media Pembelajaran Pengenalan Hardware Jaringan Komputer Berbasis Augmented Reality. Jurnal Pendidikan Informatika dan Sains, 7(1): 118-125.

Djumhadi. 2017. Model Sistem Monitoring Mesin Anjungan Tunai Mandiri (ATM) Studi Kasus pada PT. Bank Central Asia.Tbk (BCA) Balikpapan. METIK JOURNAL: Jurnal Informatika Metik STMIK STIKOM Balikpapan, 1(1): $1-9$.

Effendi, D. \& Noviansyah, B. 2018. Rancang Bangun Sistem Informasi Manajemen Persediaan Barang di Suhuf Kertaseni Nusantara Bandung. JIPI (Jurnal Ilmiah Penelitian dan Pembelajaran Informatika), 3(1): 17-23.

Halawa, S. 2016. Perancangan Aplikasi Pembelajaran Topologi Jaringan Komputer untuk Sekolah Menengah Kejuruan (SMK) Teknik Komputer dan Jaringan (TKJ) dengan Metode Computer Based Instruction. Jurnal Riset Komputer (JURIKOM), 3(1): 66-71.

Irawan, A. \& Noor, T. 2014. Sistem Informasi Absensi Mahasiswa (Studi Kasus Jurusan Administrasi Bisnis POLIBAN). Jurnal INTEKNA, 14(2): 102-109.

Kristy, R. D., Wahyuni, E. D., \& Hayatin, N. 2020. Analysis of the Readiness Level of Children Encyclopedia Using Technology Readiness Index (TRI). Jurnal Repositor, 2(2): 129-136.

Kurniadi, D. 2014. Rancang Bangun Aplikasi Sistem Pemilihan Kepala Desa yang Terintegrasi dengan SMS Gateway. Wawasan Ilmiah, 6(11): 1-7.

Lestanti, S. \& Susana, A. D. 2016. Sistem Pengarsipan Dokumen Guru dan Pegawai Menggunakan Metode Mixture Modelling Berbasis Web. Antivirus: Jurnal Ilmiah Teknik Informatika, 10(2): 69-77.

Mendra, N. P. Y. 2017. Penerapan Sistem E-Filing, Kepatuhan Wajib Pajak dan Pemahaman Internet. Jurnal Riset Akuntansi (JUARA), 7(2): 222-234.

Purabaya, T. B. 2017. Sistem Informasi Rekam Medis (Studi Kasus: Klinik Medika Prima Indramayu). Syntax Literate: Jurnal Ilmiah Indonesia, 2(9): 151-169. 
Ramadi, R. 2016. Penerapan Knowledge Management System pada Perusahaan Otomotif: Studi Kasus PT. Astrido Jaya Mobilindo. Simetris: Jurnal Teknik Mesin, Elektro dan Ilmu Komputer, 7(2): 635-648.

Sari, H. P. \& Muhartini, R. 2017. Sistem Aplikasi Pengolahan Nilai Raport SDN Tanjunganom 2 Kecamatan Tanjunganom Nganjuk. Antivirus: Jurnal Ilmiah Teknik Informatika, 11(1): 65-80.

Senna, O. Y. \& Supriyono, H. 2016. Sistem Transaksi Barang Retail Menggunakan RFID. Emitor: Jurnal Teknik Elektro, 16(2): 64-68.

Setyawan, D. I., Tolle, H., \& Kharisma, A. P. 2017. Perancangan Aplikasi Communication Board Berbasis Android Tablet Sebagai Media Pembelajaran dan Komunikasi bagi Anak Tuna Rungu. Jurnal Pengembangan Teknologi Informasi dan Ilmu Komputer, 2(8): 2933-2943.

Siregar, Y. B. 2019. Digitalisasi Arsip untuk Efisiensi Penyimpanan dan Aksesibilitas. Jurnal Administrasi dan Kesekretarisan, 4(1): 1-19.

SIRKEL Laboratorium. 2008. Modul Praktikum Pemrograman Web. Tidak diterbitkan. Yogyakarta: Universitas Islam Indonesia.

Sundari, J. 2016. Sistem Informasi Pelayanan Puskesmas Berbasis Web. Indonesian Journal on Software Engineering (IJSE), 2(1): 44-49.

Susilo, P. H. \& Rohman, M. G. 2017. Digitalisasi Sistem Manajemen MUTU ISO Berbasis Aplikasi Web. Jurnal Penelitian Teknik Informatika, 2(1): 45-50.

Syapnika, D. \& Siagian, E. R. 2015. Penerapan Algoritma Minimax pada Permainan Checkers. Jurnal Riset Komputer (JURIKOM), 2(6): 28-32.

Tinambunan, A., Ginting, G. L., \& Panjaitan, M. 2018. Perancangan Aplikasi Rambu-Rambu Lalu Lintas untuk Anak Usia Dini Berbasis Android Menggunakan CAI (Computer Assisted Instruction). Jurnal Riset Komputer (JURIKOM), 5(3): 290-295.

Ulfa, K. \& Syahrizal, M. 2016. Perancangan Aplikasi Prediksi Jumlah Siswa Baru pada Yayasan Cerdas Murni Menggunakan Exponential Smoothing. Jurnal Riset Komputer (JURIKOM), 3(6): 59-64.

Waryanto, N. \& Insani, N. 2013. Tingkat Kesiapan (Readiness) Implementasi ELearning di Sekolah Menengah Atas Kota Yogyakarta. Jurnal Pendidikan Matematika dan Sains, 1(2): 117-124.

Yudha, A. P. \& Sinatra, Y. 2016. Perancangan dan Implementasi Aplikasi Perpustakaan Berbasis Web dengan SMS Gateway Menggunakan Metode Waterfall di SMP Negeri 2 Singosari. SINTEKS:Jurnal Teknik, 5(2): 1-9.

Yunita \& Susanto, A. 2020. Merancang Media Pembelajaran Berbasis Web Menggunakan Aplikasi Dreamweaver pada SMAN 1 Kapoiala. Jurnal Sistem Informasi dan Sistem Komputer, 5(2): 9-18.

Zukri, Z. \& Winarko, E. 2014. Rancangan Business Intelligence pada Instalasi Farmasi Rumah Sakit. Prosiding Seminar Nasional Aplikasi Teknologi Informasi (SNATI), Yogyakarta: 21 Juni 2014 Hal: B46-B51. 